\title{
New Diterpenes from Cultures of the Fungus Engleromyces goetzii and Their CETP Inhibitory Activity
}

\author{
Yang Wang $\cdot$ Ling Zhang $\cdot$ Fang Wang $\cdot$ \\ Zheng-Hui Li $\cdot$ Ze-Jun Dong $\cdot$ Ji-Kai Liu
}

Received: 6 January 2015/Accepted: 31 January 2015/Published online: 8 April 2015

(c) The Author(s) 2015. This article is published with open access at Springerlink.com

\begin{abstract}
One new cleistanthane-type diterpene named engleromycenolic acid A (1), one new rosane-type diterpene named engleromycenolic acid B (2) and one new natural rosane-type diterpene, engleromycenol (3), along with three known rosanetype diterpenes, rosololactone (4), rosenonolactone (5) and 7-deoxyrosenonolactone (6) were isolated from cultures of the fungus Engleromyces goetzii, where it naturally grows on Alpine bamboo culms. The new compounds were elucidated based on their spectroscopic data. In addition, compounds 1-6 were evaluated for their cholesterol ester transfer protein (CETP) inhibition activity. This paper reports the isolation, structural elucidation, and CETP inhibition activity of these compounds.
\end{abstract}

Keywords Engleromyces goetzii - Engleromycenolic acid A · Engleromycenolic acid B · Engleromycenol $\cdot$ CETP

\section{Introduction}

The fungus Engleromyces goetzii is widely distributed in Tibet, Sichuan and Yunnan province. It grows on Alpine bamboo culms, and ripens during rainy season from July to August. Local residents usually boil the fruiting bodies in water to treat infection, inflammation and cancer [1-3]. Previous investigation on the fruiting bodies of E. goetzii has led to the isolation of neoengleromycin, cytochalasin $\mathrm{D}$ and 19,20-epoxycytochalasin D [4-6]. There are no reports about the chemical constituents of the cultures of this fungus.

Electronic supplementary material The online version of this article (doi:10.1007/s13659-015-0055-5) contains supplementary material, which is available to authorized users.

Y. Wang · L. Zhang · F. Wang · Z.-H. Li · Z.-J. Dong ·

J.-K. Liu $(\bowtie)$

State Key Laboratory of Phytochemistry and Plant Resources in West China, Kunming Institute of Botany, Chinese Academy of Sciences, Kunming 650201, China

e-mail: jkliu@mail.kib.ac.cn

Y. Wang $\cdot$ F. Wang

University of Chinese Academy of Sciences, Beijing 100049, China
In order to search for more novel and potentially bioactive secondary metabolites, the chemical constituents of $E$. goetzii cultures were investigated by altering the culture conditions of the fungus and enlarging the fermentation scale. This investigation led to the isolation and identification of one new cleistanthane-type diterpene named engleromycenolic acid A (1), one new rosane-type diterpene named engleromycenolic acid B (2) and one new natural rosane-type diterpene named engleromycenol (3), along with three known rosane-type diterpenes: rosololactone (4), rosenonolactone (5) and 7-deoxyrosenonolactone (6) [7]. Their structures (Fig. 1) were elucidated based on the spectroscopic data analyses. The cholesterol ester transfer protein (CETP) inhibition activities of compounds $\mathbf{1 - 6}$ were examined and engleromycenolic acid A (1) showed CETP inhibition activity with $\mathrm{IC}_{50}$ value at $7.55 \mu \mathrm{M}$.

There are two kinds of lipoproteinsin plasma: one is low-density lipoprotein (LDL) and another is high-density lipoprotein (HDL) $[8,9]$. They are in charge of carrying cholesteryl esters in plasma. HDL is responsible for transferring cholesteryl esters from periphery plasma to the liver to metabolize, and LDL mediates the transport of cholesteryl esters from the liver to periphery plasma $[8,10$, 11]. CETP promotes the transfer of cholesteryl esters from 

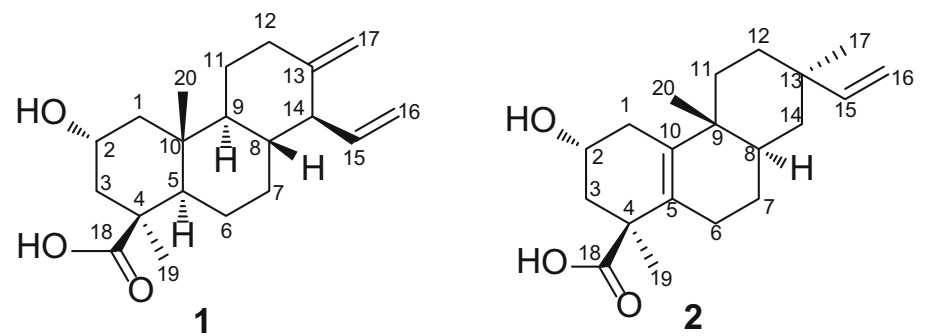<smiles>C=C[C@]1(C)CC[C@]2(C)C3=C(CC[C@H]2C1)[C@@](C)(CO)CCC3</smiles>

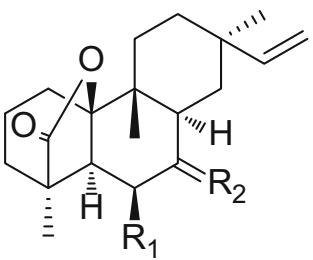

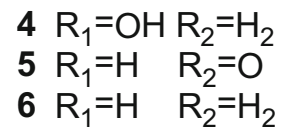

Fig. 1 Structures of compounds 1-6

HDL to LDL. Inhibiting the activity of CETP can promotes the metabolism of cholesteryl esters in the liver and avoids accumulation of cholesterol esters in plasma that may cause atherosclerosis [9, 11-14].

\section{Results and Discussion}

Compound 1 was obtained as colorless oil, displayed an $[\mathrm{M}+\mathrm{Na}]^{+}$ion at $m / z 341.2096$ on the positive HRESIMS analysis, corresponding to the molecular formula $\mathrm{C}_{20} \mathrm{H}_{30} \mathrm{O}_{3}$ with six degrees of unsaturation. The ${ }^{1} \mathrm{H}$ NMR spectrum of 1 (Table 1) exhibited two methyls at $\delta_{\mathrm{H}} 1.28(3 \mathrm{H}, \mathrm{s})$ and $0.80(3 \mathrm{H}, \mathrm{s})$, five olefinic protons at $\delta_{\mathrm{H}} 5.69(1 \mathrm{H}$, ddd, $J=17.1,10.0,10.0 \mathrm{~Hz}), 5.16(1 \mathrm{H}, \mathrm{dd}, J=10.0,2.2 \mathrm{~Hz})$, $5.00(1 \mathrm{H}, \mathrm{dd}, J=17.1,2.2 \mathrm{~Hz}), 4.67(1 \mathrm{H}$, br.s $)$ and 4.57 (1H, br.s). The ${ }^{13} \mathrm{C}$ NMR spectrum showed 20 carbon resonances, including one carboxyl, four $s p^{2}$ olefinic carbons, one oxygen-bearing methine, two tertiary methyls, six methylenes, four methines as well as two quaternary carbons. These data suggested compound 1 might be a tricyclic diterpene. The ${ }^{1} \mathrm{H}$ and ${ }^{13} \mathrm{C}$ NMR spectral data of $\mathbf{1}$ were similar to those of auricularic acid [15], which indicated that 1 was a cleistanthane-type diterpene. However, there are certain differences as follows: the resonance of C-2 at $\delta_{\mathrm{C}} 19.5$ in auricularic acid is down shifted to $\delta_{\mathrm{C}} 65.3$ in 1, suggesting that the methylene at $\mathrm{C}-2$ was replaced by an oxygen-bearing methine. Furthermore, the HMBC correlations from $\delta_{\mathrm{H}} 2.41,2.13,1.00,0.93$ to carbon at $\delta_{\mathrm{C}}$ 65.3, and the ${ }^{1} \mathrm{H}-{ }^{1} \mathrm{H}$ COSY correlations from $\delta_{\mathrm{H}} 4.14$ to $\delta_{\mathrm{H}}$ $2.41,2.13,1.00$ and 0.93 in $\mathbf{1}$, indicating that the oxygenbearing methane was placed at C-2. According to the molecular formula, we can conclude the oxygen-bearing methine at $\mathrm{C}-2$ in $\mathbf{1}$ was substituted by a hydroxyl. In the ROSEY spectrum, the observed cross peaks of $\mathrm{CH}_{3}-20 / \mathrm{H}-$
$6 \beta, \mathrm{H}-2 / \mathrm{CH}_{3}-20, \mathrm{CH}_{3}-20 / \mathrm{H}-8, \mathrm{H}-8 / \mathrm{H}-15$ and $\mathrm{H}-15 / \mathrm{H}-7 \beta$ suggested that $\mathrm{H}-2, \mathrm{H}-8, \mathrm{H}-15 \mathrm{H}-7 \beta, \mathrm{H}-6 \beta$ and $\mathrm{CH}_{3}-20$ were in the same side, whereas the cross peaks of $\mathrm{H}-6 \alpha$ / $\mathrm{CH}_{3}-19, \mathrm{H}-9 / \mathrm{H}-14, \mathrm{H}-7 \alpha / \mathrm{H}-14$ and $\mathrm{H}-7 \alpha / \mathrm{H}-5$ indicated that H-6 $\alpha, \mathrm{CH}_{3}-19, \mathrm{H}-9, \mathrm{H}-14, \mathrm{H}-7 \alpha, \mathrm{H}-14$ and $\mathrm{H}-5$ lied on the opposite side (Fig. 2). Therefore, 1 was determined as engleromycenolic acid $\mathrm{A}$.

Compound 2 was isolated as white powder. The molecular formula $\mathrm{C}_{20} \mathrm{H}_{30} \mathrm{O}_{3}$ was determined by the HRESIMS analysis $\left(\mathrm{m} / \mathrm{z}, 341.2091[\mathrm{M}+\mathrm{Na}]^{+}\right)$, which indicated six degrees of unsaturation. The ${ }^{1} \mathrm{H}$ NMR spectrum (Table 2) of 2 exhibited three olefinic protons at $\delta_{\mathrm{H}} 5.87(1 \mathrm{H}, \mathrm{dd}, J=17.5,10.7 \mathrm{~Hz})$, $4.97(1 \mathrm{H}, \mathrm{dd}, J=17.5,1.0 \mathrm{~Hz})$ and $4.88(1 \mathrm{H}, \mathrm{dd}, J=10.7$, $1.0 \mathrm{~Hz})$, one oxygen-bearing methine at $\delta_{\mathrm{H}} 3.95(1 \mathrm{H}, \mathrm{m})$ and three methyls at $\delta_{\mathrm{H}} 0.98(3 \mathrm{H}, \mathrm{s}), 1.08(3 \mathrm{H}, \mathrm{s})$ and $1.31(3 \mathrm{H}, \mathrm{s})$. The ${ }^{13} \mathrm{C}$ NMR spectrum showed 20 carbon resonances including one carbonyl, four olefinic carbons, one oxygenbearing methine, three methyls, seven methylenes, one methine and three quaternary carbons. Comparison of NMR data of 2 with those of 7-deoxyrosenonolactone (6) [16], revealed the presence of the characteristic signals of a rosane-type diterpene. The resonances at $\delta_{\mathrm{C}} 129.5$ and 138.8 in the ${ }^{13} \mathrm{C}$ NMR spectrum of $\mathbf{2}$ suggested there was an additional double bond in 2. The HMBC correlations from $\delta_{\mathrm{H}} 2.42$ and 1.86 to $\delta_{\mathrm{C}}$ $129.5, \delta_{\mathrm{H}} 1.31$ to $\delta_{\mathrm{C}} 129.5 ; \delta_{\mathrm{H}} 2.22$ and 1.97 to $\delta_{\mathrm{C}} 138.8$ as well as $\delta_{\mathrm{H}} 0.98$ to $\delta_{\mathrm{C}} 138.8$, indicated that the new double bond located between $\mathrm{C}-5$ and $\mathrm{C}-10$. Based on the analysis, the oxygen linkage between $\mathrm{C}-10$ and $\mathrm{C}-18$ in $\mathbf{6}$ was broken and formed a carboxyl at $\mathrm{C}-18$ in $\mathbf{2}$, which was confirmed by the HMBC correlations from $\delta_{\mathrm{H}} 2.21,1.41$ and 1.31 to $\delta_{\mathrm{C}} 180.9$. In addition, the resonance of $\delta_{\mathrm{C}} 21.7(\mathrm{t})$ in 6 is down shifted to $\delta_{\mathrm{C}} 66.2(\mathrm{~d})$ in 2 , indicated the methylene is oxidized by a hydroxyl. The HMBC correlations from $\delta_{\mathrm{H}} 2.42,2.21,1.86$ and 1.41 to carbon at $\delta_{\mathrm{C}} 66.2$, as well as the ${ }^{1} \mathrm{H}-{ }^{1} \mathrm{H}$ COSY correlations from $\delta_{\mathrm{H}} 3.95$ to $\delta_{\mathrm{H}} 2.42,2.21,1.86$ and 1.41, 
Table $1{ }^{1} \mathrm{H}$ and ${ }^{13} \mathrm{C}$ NMR spectroscopic data for compound $\mathbf{1}$

\begin{tabular}{|c|c|c|}
\hline Pos. & $\delta_{\mathrm{C}}$ Type & $\delta_{\mathrm{H}}(J$ in $\mathrm{Hz})$ \\
\hline 1 & $49.3, \mathrm{t}$ & $\begin{array}{l}2.13 \text { (ddd } 12.3,4.3,1.9, \mathrm{H}-\beta) \\
0.93 \text {, overlapped }\end{array}$ \\
\hline 2 & $65.3, \mathrm{~d}$ & $4.14(\mathrm{tt}, 11.5,4.3, \mathrm{H}-\beta)$ \\
\hline 3 & $47.7, \mathrm{t}$ & $\begin{array}{l}2.41(\mathrm{ddd} 12.3,4.3,1.9, \mathrm{H}-\beta) \\
1.00, \text { overlapped }\end{array}$ \\
\hline 4 & $46.0, \mathrm{~s}$ & \\
\hline 5 & $56.6, \mathrm{~d}$ & 1.15 , overlapped \\
\hline 6 & $24.3, \mathrm{t}$ & $\begin{array}{l}\text { 1.92, overlapped } \\
1.74(\text { dddd } 13.5,13.5,13.5,3.5, \mathrm{H}-\beta)\end{array}$ \\
\hline 7 & $35.3, \mathrm{t}$ & $\begin{array}{l}2.02(\mathrm{dq}-\text {-like, } 13.3,3.6, \mathrm{H}-\beta) \\
0.89(\mathrm{qd}-\mathrm{like}, 13.3,3.6, \mathrm{H}-\alpha)\end{array}$ \\
\hline 8 & $42.8, \mathrm{~d}$ & 1.17, overlapped \\
\hline 9 & $55.8, \mathrm{~d}$ & 1.03, overlapped \\
\hline 10 & $40.0, \mathrm{~s}$ & \\
\hline 11 & $28.1, \mathrm{t}$ & $\begin{array}{l}1.93, \text { overlapped, } \mathrm{H}-\alpha \\
1.12, \text { overlapped, } \mathrm{H}-\beta\end{array}$ \\
\hline 12 & $37.0, \mathrm{t}$ & $\begin{array}{l}2.45(\mathrm{ddd}, 13.1,3.2,3.2, \mathrm{H}-\beta) \\
2.06, \text { overlapped }\end{array}$ \\
\hline 13 & $152.4, \mathrm{~s}$ & \\
\hline 14 & $56.0, \mathrm{~d}$ & $2.28(\mathrm{dd}, 10.0,10.0)$ \\
\hline 15 & $141.2, \mathrm{~d}$ & $5.69(\mathrm{ddd}, 17.1,10.0,10.0)$ \\
\hline 16 & $116.9, \mathrm{t}$ & $\begin{array}{l}5.16(\mathrm{dd}, 10.0,2.2) \\
5.00(\mathrm{dd}, 17.1,2.2)\end{array}$ \\
\hline 17 & $106.8, \mathrm{t}$ & $\begin{array}{l}4.67 \text { br.s } \\
4.57 \text { br.s }\end{array}$ \\
\hline 18 & $181.2, \mathrm{~s}$ & \\
\hline 19 & $29.5, \mathrm{q}$ & $1.28, \mathrm{~s}$ \\
\hline 20 & $14.4, \mathrm{q}$ & $0.80, \mathrm{~s}$ \\
\hline
\end{tabular}

Spectra were measured in $\mathrm{CD}_{3} \mathrm{OD}$ at $600 \mathrm{MHz}$

suggesting the hydroxyl was attached to C-2. The ROSEY spectrum showed cross peaks between $\mathrm{CH}_{3}-20 / \mathrm{H}-2, \mathrm{H}-1 \beta$ / $\mathrm{CH}_{3}-20, \mathrm{H}-1 \alpha / \mathrm{H}-8, \mathrm{H}-8 / \mathrm{H}-6 \alpha, \mathrm{CH}_{3}-19 / \mathrm{H}-6 \alpha$ and $\mathrm{CH}_{3}-17 / \mathrm{H}-8$ suggested $\mathrm{CH}_{3}-20, \mathrm{H}-2, \mathrm{H}-1 \beta$ in the same side, and $\mathrm{H}-1 \alpha, \mathrm{H}-8$,
$\mathrm{H}-6 \alpha, \mathrm{CH}_{3}-19$ and $\mathrm{CH}_{3}-17$ in the opposite side (Fig. 3). The detailed analysis of chemical shift and coupling constant led to the determination that compound $\mathbf{2}$ was elucidated as engleromycenolic acid B.

Compound 3 possessed a molecular formula $\mathrm{C}_{20} \mathrm{H}_{32} \mathrm{O}$ as determined by the HRESIMS $\left(\mathrm{m} / \mathrm{z} 311.2354,[\mathrm{M}+\mathrm{Na}]^{+}\right)$, which implied five degrees of unsaturation. The 1D NMR spectroscopic data (Table 2) suggested that the backbone of $\mathbf{3}$ was the same as that of $\mathbf{2}$. Differences between them were identified to be the loss of a carbonyl and an oxygen-bearing methine, as well as the appearance of a hydroxymethyl and a methylene. The HMBC correlations of $\delta_{\mathrm{H}} 3.58$ and 3.32 with $\delta_{\mathrm{C}} 23.6,34.9$ and 128.7 suggested the carbonyl at C-18 in $\mathbf{2}$ is replaced by the hydroxymethyl $\left(\delta_{\mathrm{C}} 69.9, \delta_{\mathrm{H}} 3.58\right.$ and 3.32$)$ in 3. In addition, the $\mathrm{HMBC}$ correlation from $\delta_{\mathrm{H}} 1.68$ and 1.58 to $\delta_{\mathrm{C}} 142.5$ and 39.3 , and the ${ }^{1} \mathrm{H}-{ }^{1} \mathrm{H}$ COSY correlation from $\delta_{\mathrm{H}}$ 1.98 to $\delta_{\mathrm{H}} 1.68$ and $1.58, \delta_{\mathrm{H}} 1.68$ and 1.58 to $\delta_{\mathrm{H}} 1.78$ and 1.27 , indicated that the oxygen-bearing methine at $\mathrm{C}-2$ in 2 was replaced by a methylene in 3 . The configuration of C-8, C-9 and $\mathrm{C}-13$ were established by comparing the NMR data of $\mathbf{3}$ with 2 . The H-3 signal at $\delta_{\mathrm{H}} 1.78(1 \mathrm{H}$, ddd, $J=13.5,5.0$, $3.5 \mathrm{~Hz}$ ) suggested it to be equatorial $\beta$-oriented. In the ROSEY spectrum, the observed cross peak of $\delta_{\mathrm{H}} 1.78$ and 3.32 indicated the hydroxymethyl group in C-4 was located in axial $\beta$-oriented. In addition, there are no cross peak between $\mathrm{H}-18$ $(3.58,3.32)$ and $\mathrm{H}-3 \alpha(1.27)$ in ROSEY spectrum, which further approved the conclusion above (Fig. 4). According to this analysis, compound $\mathbf{3}$ was confirmed as engleromycenol.

Based on the spectroscopic analyses and the comparison with the literature, the known compounds were identified as rosololactone (4) [17, 18], rosenonolactone (5) [18] and 7-deoxyrosenonolactone (6) [16]. Compound 3 has been reported in the conversion of 7-deoxyrosenonolactone to $\mathbf{3}$ by Connolly [19]. However, there are no reports about the NMR data of 3.

All the isolates were assayed for their CETP inhibition activity with the CETP Inhibitor Drug Screening Kit. The result showed that compounds 2-6 exhibited weak
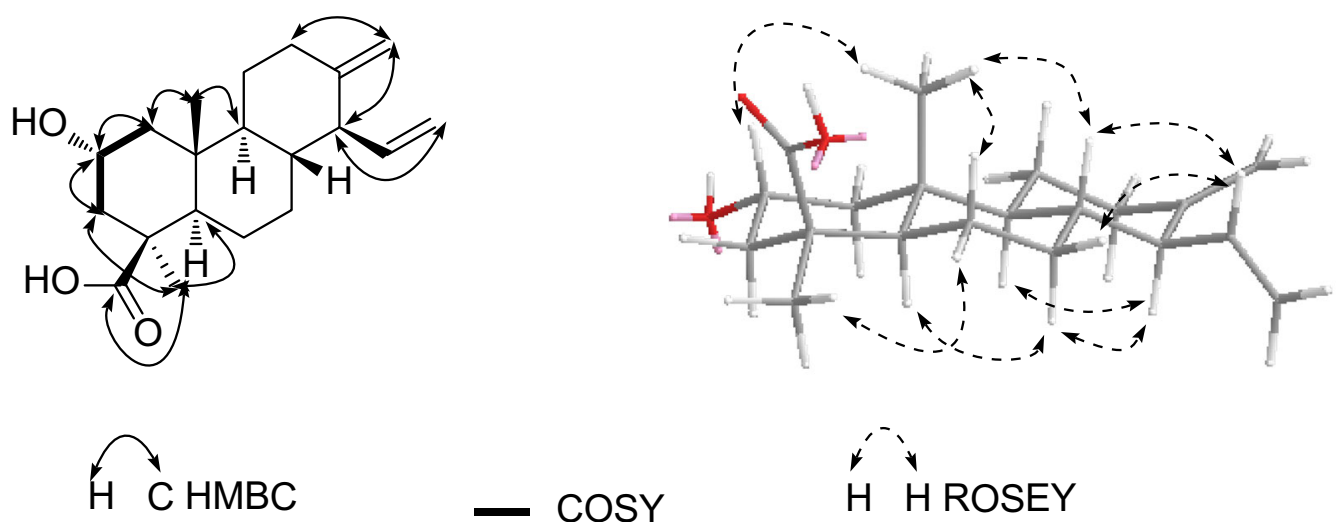

Fig. 2 Selected 2D NMR correlations of 1 
Table $2{ }^{1} \mathrm{H}$ and ${ }^{13} \mathrm{C}$ NMR spectroscopic data for compounds $\mathbf{2}$ and $\mathbf{3}$

\begin{tabular}{|c|c|c|c|c|}
\hline \multirow[t]{2}{*}{ Pos. } & \multicolumn{2}{|l|}{$2^{\mathrm{a}}$} & \multicolumn{2}{|l|}{$3^{b}$} \\
\hline & $\delta_{\mathrm{C}}$ Type & $\delta_{\mathrm{H}}(J$ in $\mathrm{Hz})$ & $\delta_{\mathrm{C}}$ Type & $\delta_{\mathrm{H}}(J$ in $\mathrm{Hz})$ \\
\hline 1 & $35.4, \mathrm{t}$ & $\begin{array}{l}2.42(\mathrm{dd}, 15.9,3.8, \mathrm{H}-\beta) \\
1.86, \mathrm{~m}, \mathrm{H}-\alpha\end{array}$ & $25.0, \mathrm{t}$ & 1.98, overlapped \\
\hline 2 & $66.2, d$ & $3.95, \mathrm{~m}$ & $19.7, \mathrm{t}$ & $\begin{array}{l}1.68, \text { overlapped } \\
1.58, \text { overlapped }\end{array}$ \\
\hline 3 & $45.8, \mathrm{t}$ & $\begin{array}{l}2.21, \text { overlapped } \\
1.41, \text { overlapped }\end{array}$ & $34.9, \mathrm{t}$ & $\begin{array}{l}1.78(\mathrm{ddd}, 13.5,5.0,3.5, \mathrm{H}-\beta) \\
1.27 \text {, overlapped }\end{array}$ \\
\hline 4 & $49.8, \mathrm{~s}$ & & $39.3, \mathrm{~s}$ & \\
\hline 5 & $129.5, \mathrm{~s}$ & & $128.7, \mathrm{~s}$ & \\
\hline 6 & $28.1, \mathrm{t}$ & $\begin{array}{l}\text { 2.22, overlapped, } \mathrm{H}-\alpha \\
1.97(\mathrm{dd}, 16.9,5.4, \mathrm{H}-\beta)\end{array}$ & $25.2, \mathrm{t}$ & $\begin{array}{l}2.10, \text { overlapped } \\
1.96, \text { overlapped }\end{array}$ \\
\hline 7 & $26.5, \mathrm{t}$ & $\begin{array}{l}1.51, \text { overlapped } \\
1.34 \text {, overlapped }\end{array}$ & $25.8, \mathrm{t}$ & $\begin{array}{l}1.39, \text { overlapped } \\
1.32, \text { overlapped }\end{array}$ \\
\hline $\begin{array}{l}8 \\
9\end{array}$ & $\begin{array}{l}38.9, \mathrm{~d} \\
38.6, \mathrm{~s}\end{array}$ & 1.65 , overlapped & $\begin{array}{l}37.5, \mathrm{~d} \\
37.8, \mathrm{~s}\end{array}$ & 1.59 , overlapped \\
\hline 10 & $138.8, \mathrm{~s}$ & & $142.5, \mathrm{~s}$ & \\
\hline 11 & $32.6, \mathrm{t}$ & $\begin{array}{l}1.68, \text { overlapped } \\
1.39, \text { overlapped }\end{array}$ & $31.7, \mathrm{t}$ & $\begin{array}{l}1.61, \text { overlapped } \\
1.33, \text { overlapped }\end{array}$ \\
\hline 12 & $33.5, \mathrm{t}$ & $\begin{array}{l}1.64, \text { overlapped } \\
1.33, \text { overlapped }\end{array}$ & $32.7, \mathrm{t}$ & $\begin{array}{l}1.54, \text { overlapped } \\
1.27, \text { overlapped }\end{array}$ \\
\hline 13 & $37.3, \mathrm{~s}$ & & $36.4, \mathrm{~s}$ & \\
\hline 14 & $40.6, \mathrm{t}$ & $\begin{array}{l}1.48, \text { overlapped, H- } \beta \\
1.13 \text { (br.d, } 13.1, \mathrm{H}-\alpha \text { ) }\end{array}$ & $39.8, \mathrm{t}$ & $\begin{array}{l}1.38, \text { overlapped } \\
1.07, \text { overlapped }\end{array}$ \\
\hline 15 & $152.2, \mathrm{~d}$ & $5.87(\mathrm{dd}, 17.5,10.7)$ & $151.4, \mathrm{~d}$ & $5.82(\mathrm{dd}, 17.4,10.7)$ \\
\hline 16 & $109.2, \mathrm{t}$ & $\begin{array}{l}4.97(\mathrm{dd}, 17.5,1.0) \\
4.88(\mathrm{dd}, 10.7,1.0)\end{array}$ & $108.8, \mathrm{t}$ & $\begin{array}{l}4.92(\mathrm{dd}, 17.4,1.2) \\
4.85(\mathrm{dd}, 10.7,1.2)\end{array}$ \\
\hline 17 & $23.5, \mathrm{q}$ & $1.08, \mathrm{~s}$ & $23.1, \mathrm{q}$ & $1.03, \mathrm{~s}$ \\
\hline 18 & $180.9, \mathrm{~s}$ & & $69.9, \mathrm{t}$ & $\begin{array}{l}3.58(\mathrm{~d}, 10.8) \\
3.32(\mathrm{~d}, 10.8)\end{array}$ \\
\hline 19 & 25.3, q & $1.31, \mathrm{~s}$ & 23.6, q & $0.95, \mathrm{~s}$ \\
\hline 20 & 16.7, q & $0.98, \mathrm{~s}$ & $17.9, \mathrm{q}$ & $0.88, \mathrm{~s}$ \\
\hline
\end{tabular}

a Spectra were measured in $\mathrm{CD}_{3} \mathrm{OD}$ at $600 \mathrm{MHz}$

b Spectra were measured in $\mathrm{CDCl}_{3}$ at $400 \mathrm{MHz}$

inhibition activity of CETP, however, engleromycenolic acid A (1) significantly inhibited the activity of CETP with the $\mathrm{IC}_{50}$ value at $7.55 \mu \mathrm{M}$. Results of the study suggested that engleromycenolic acid A (1) might be a good candidate to develop effective therapeutic agent for the treatment of atherosclerotic cardiovascular diseases.

\section{Experimental Section}

\subsection{General Experimental Procedures}

The optical rotations were measured on a JASCO model 1020 polarimeter (JASCO International Co., Ltd., Tokyo, Japan). The IR spectra were obtained on a Bruker TENSOR 27FT-IR spectrometer (Bruker, Ettlingen, Germany) using $\mathrm{KBr}$ pellets. The 1D and 2D NMR data were performed on Bruker Avance III 600 and AM-400 instruments (Bruker, Rheinstetten, Germany) at room temperature. The chemical shifts $(\delta)$ were expressed in ppm with reference to the solvent signals. The mass spectra (MS) were acquired on an API QSTAR time-offlight mass spectrometer (MDS Sciex, Ontario, Canada) or a VG Autospec-3000 spectrometer (VG, Manchester, England). Silica gel (200-300 mesh, Qingdao Marine Chemical Inc., Qingdao, China), Sephadex LH-20 (Amersham Biosciences, Sweden), and RP-18 gel (40-75 $\mu$ m, Fuji Silysia Chemical Ltd., Japan) were used for column chromatography. Preparative HPLC (Prep-HPLC) was performed on an Agilent 1100 liquid chromatography system equipped with a ZORBAX SB-C ${ }_{18}$ column $(9.4 \mathrm{~mm} \times 150 \mathrm{~mm})$. Precoated silica 


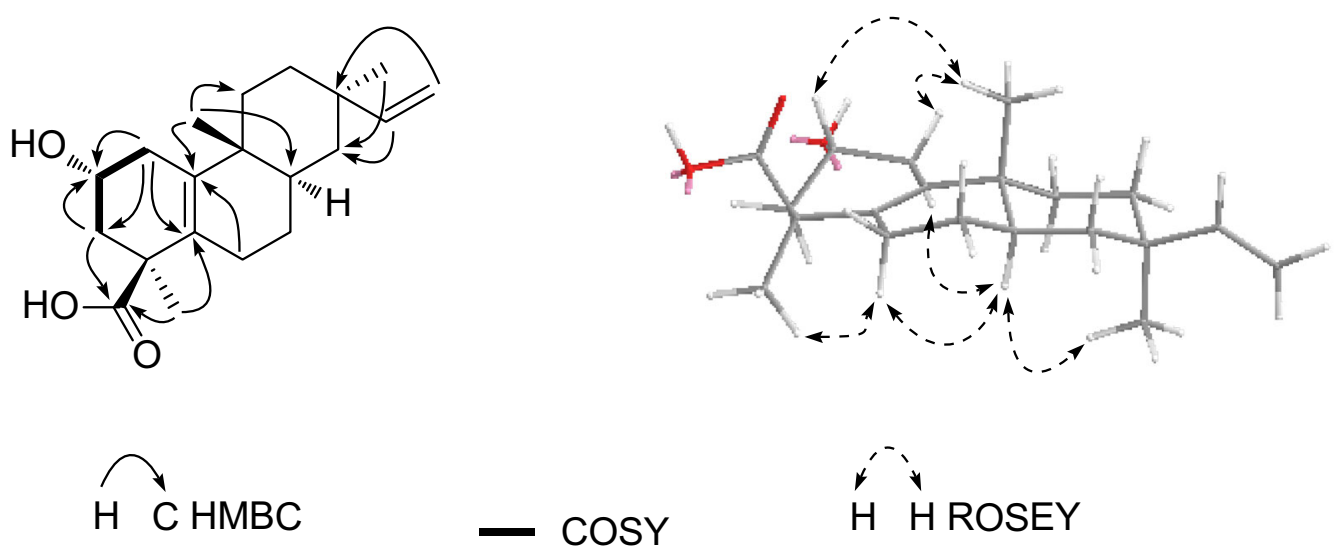

Fig. 3 Selected 2D NMR correlations of 2
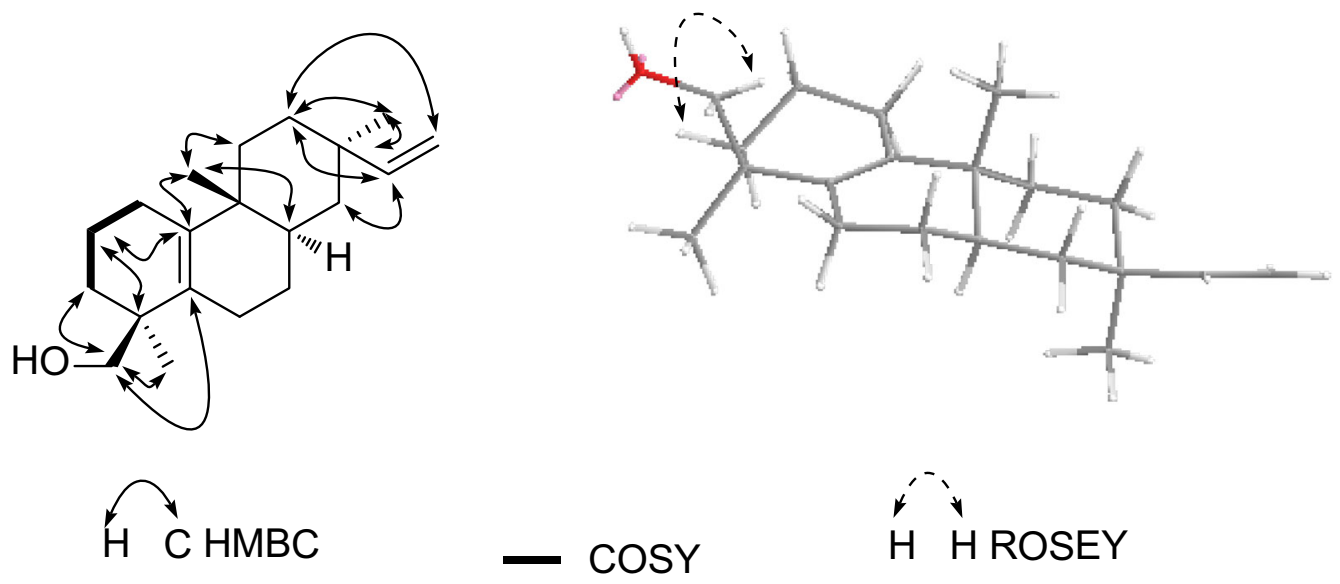

Fig. 4 Selected 2D NMR correlations of $\mathbf{3}$

gel GF254 plates (Qingdao Marine Chemical Inc., Qingdao, China) were used for TLC analysis. The fractions were monitored by TLC analysis, and spots were visualized under UV light (254 or $365 \mathrm{~nm}$ ) or by heating silica gel plates sprayed with $10 \% \mathrm{H}_{2} \mathrm{SO}_{4}$ in ethanol.

\subsection{Fungal Material and Cultivation Conditions}

Fruiting bodies of E. goetzii were collected from Shangri-La county in Yunnan Province, China. A voucher specimen has been deposited in the Herbarium of the Kunming Institute of Botany of the Chinese Academy of Sciences. The mycelia cultures were derived from the tissue plugs. The culture PDA medium consisted of glucose $(5 \%)$, peptone from porcine meat $(0.15 \%)$, yeast powder $(0.5 \%), \mathrm{KH}_{2} \mathrm{PO}_{4}(0.05 \%)$ and $\mathrm{MgSO}_{4}(0.05 \%)$. The inoculums of E. goetzii were prepared in a $15 \mathrm{~L}$-fermentation tank for 6 days under the following conditions: culture temperature, $24{ }^{\circ} \mathrm{C}$; initial $\mathrm{pH}, 6.0$; agitation speed, $250 \mathrm{r} / \mathrm{min}$; inoculation volume, $10 \%$ (by volume); and aeration rate, 1.0 volume/culture volume/min. Subsequently, the liquid seed was transferred into a 100
L-fermentation tank for cultivation under the same conditions for 20 days to afford an $80 \mathrm{~L}$ culture broth.

\subsection{Extraction and Isolation}

The fermentation broth $(80 \mathrm{~L})$ was filtered, and the filtrate was concentrated to $10 \mathrm{~L}$ under reduced pressure and then extracted with ethyl acetate $(3 \times 10 \mathrm{~L})$. The organic layer was evaporated to give a crude extract $(350 \mathrm{~g})$. Subsequently, the extract was subjected to silica gel column chromatography, using a petroleum ether/acetone gradient $(100: 0 \rightarrow 0: 100 \mathrm{~V} / \mathrm{V})$ to afford fractions $\mathrm{F}_{1}-\mathrm{F}_{7}$ based on TLC analysis. $\mathrm{F}_{3}$ was purified using Sephadex LH-20 column chromatography (chloroform/methanol $=1: 1 \mathrm{~V} / \mathrm{V}$ ) and then subjected to silica gel column chromatography (petroleum ether/acetone $=100: 1 \mathrm{~V} / \mathrm{V})$ to afford compound $6(50.0 \mathrm{mg}) . \mathrm{F}_{4}$ was fractioned by Sephadex LH-20 (chloroform/methanol $=1: 1 \mathrm{~V} / \mathrm{V}$ ) and then subjected to silica gel with a petroleum ether/acetone system $(150: 1 \mathrm{~V} / \mathrm{V})$ to give compound $5(15.1 \mathrm{mg}) . \mathrm{F}_{5}$ was separated by silica gel column chromatography (chloroform/methanol $=100: 1 \mathrm{~V} / \mathrm{V}$ ) to yield 
$\mathrm{F}_{5-1}$ and $\mathrm{F}_{5-2} . \mathrm{F}_{5-1}$ was further purified by Sephadex LH-20 column chromatography (chloroform/methanol $=1: 1 \mathrm{~V} / \mathrm{V}$ ) to afford compound $4(13.3 \mathrm{mg})$. $\mathrm{F}_{5-2}$ was separated with silica gel column chromatography (chloroform/methanol $=150: 1 \mathrm{~V} / \mathrm{V}$ ) and Sephadex LH-20 column chromatography (chloroform/methanol $=1: 1 \mathrm{~V} / \mathrm{V}$ ) to give $\mathrm{F}_{5-2-1}$ and $\mathrm{F}_{5-2-2} . \mathrm{F}_{5-2-1}$ was separated by preparative HPLC (acetonitrile/water $=3: 7 \rightarrow 6: 4 \mathrm{~V} / \mathrm{V})$ to provide compound $\mathbf{1}$ $(18.0 \mathrm{mg})$ and $2(10.6 \mathrm{mg}) . \mathrm{F}_{7}$ was purified by Sephadex LH20 column chromatography (chloroform/methanol $=1: 1$ $\mathrm{V} / \mathrm{V})$ and RP-18 gel (methanol/water $=1: 1 \mathrm{~V} / \mathrm{V})$ to give compound $\mathbf{3}(30.8 \mathrm{mg})$.

\subsection{Engleromycenolic Acid A (1)}

Colorless oil; $[\alpha]_{\mathrm{D}}^{21.2}+30.5(c 0.23, \mathrm{MeOH}) ; \mathrm{IR}(\mathrm{KBr}) v_{\max }$ 3446, 3080, 2943, 2863, 1693, 1642, 1467, 1447, $1200 \mathrm{~cm}^{-1} ;{ }^{1} \mathrm{H}$ and ${ }^{13} \mathrm{C}$ NMR data see Table 1; ESIMS (negative) $\mathrm{m} / \mathrm{z} 317(100)[\mathrm{M}-\mathrm{H}]^{-}$; HRESIMS (positive) $\mathrm{m} / \mathrm{z}$ $341.2096[\mathrm{M}+\mathrm{Na}]^{+}$(calcd for $\mathrm{C}_{20} \mathrm{H}_{30} \mathrm{O}_{3} \mathrm{Na}, 341.2093$ ).

\subsection{Engleromycenolic Acid B (2)}

White powder; $[\alpha]_{\mathrm{D}}^{24.6}-166.3(c 0.32, \mathrm{MeOH})$; IR $(\mathrm{KBr}) v_{\max }$ 3440, 3082, 2928, 2871, 1700, 1635, 1465, $1233 \mathrm{~cm}^{-1} ;{ }^{1} \mathrm{H}$ protein gene family. CETP transfers neutral lipids from HDL to LDL and is present in normal human plasma and serum. The CETP Drug Screening Kit uses a donor molecule containing a fluorescent self-quenched neutral lipid that is transferred to an acceptor molecule in the presence of CETP (rabbit serum). CETP-mediated transfer of the fluorescent neutral lipid to the acceptor molecule results in an increase in fluorescence $($ ExEm $=465 / 535 \mathrm{~nm})$. Inhibitor of CETP will inhibit the lipid transfer and subsequently decrease fluorescence intensity. The assay was carried out in a microtiter plate. Reagents were kept on ice prior to setting up the assay. The reaction mixture, containing test sample in $160 \mu \mathrm{L}$ $\mathrm{dH}_{2} \mathrm{O}$ or control vehicle $\left(160 \mu \mathrm{L} \mathrm{dH}_{2} \mathrm{O}\right) ; 20 \mu \mathrm{L}$ CETP assay buffer; $10 \mu \mathrm{L}$ of donor molecule and $10 \mu \mathrm{L}$ of acceptor molecule was mixed well. The reaction was initiated by the addition of $3 \mu \mathrm{L}$ of rabbit serum. After $60 \mathrm{~min}$ of incubation at $37^{\circ} \mathrm{C}$, transfer was measured by the fluorescence intensity with BioTek Instrument (Gene Company Limited., USA). Background values were obtained from a blank with $160 \mu \mathrm{L} \mathrm{dH}_{2} \mathrm{O}$. Percent inhibition of CETP activity was calculated by subtracting the background values from both control and test sample values. The $\mathrm{IC}_{50}$ value was calculated by Reed and Muench's method.

$\%$ Inhibition $=100 \times\left[1-\frac{\text { Sample (fluorescence intensity) }- \text { Background (fluorescence intensity) }}{\text { Control (fluorescence intensity) }- \text { Background (fluorescence intensity) }}\right]$

and ${ }^{13} \mathrm{C}$ NMR data see Table 2; ESIMS (negative) $\mathrm{m} / \mathrm{z} 317$ (100) $\quad[\mathrm{M}-\mathrm{H}]^{-} ;$HRESIMS (positive) $\mathrm{m} / \mathrm{z} \quad 341.2091$ $[\mathrm{M}+\mathrm{Na}]^{+}$(calcd for $\mathrm{C}_{20} \mathrm{H}_{30} \mathrm{O}_{3} \mathrm{Na}, 341.2093$ ).

\subsection{Engleromycenol (3)}

White powder; $[\alpha]_{\mathrm{D}}^{24.5}-139.1(c 0.13, \mathrm{MeOH})$; IR $(\mathrm{KBr})$ $v_{\max } 3440,3082,2927,2876,1637,1462,1434,1376$, $1199 \mathrm{~cm}^{-1} ;{ }^{1} \mathrm{H}$ and ${ }^{13} \mathrm{C}$ NMR data see Table 2; ESIMS (positive) $\mathrm{m} / z 311(40)[\mathrm{M}+\mathrm{Na}]^{+}$; HRESIMS (positive) $\mathrm{m} / \mathrm{z} 311.2354[\mathrm{M}+\mathrm{Na}]^{+}$(calcd for $\mathrm{C}_{20} \mathrm{H}_{32} \mathrm{ONa}, 311.2351$ ).

\subsection{CETP Inhibition Activity Assay}

Cholesterol ester transfer protein inhibition activity assay were carried out using a CETP Inhibitor Screening Kit (BioVision Incorporated., Milpitas, USA). CETP is a member of the lipid transfer/lipopolysaccharide binding
Acknowledgments This work was financially supported by the National Science \& Technology Pillar Program of China (2012BAD23B0305 and 2013BAI11B02), the National Natural Sciences Foundation of China (U1132607, 21302194).

Conflict of interest The authors declare no competing financial interest.

Open Access This article is distributed under the terms of the Creative Commons Attribution 4.0 International License (http:// creativecommons.org/licenses/by/4.0/), which permits unrestricted use, distribution, and reproduction in any medium, provided you give appropriate credit to the original author(s) and the source, provide a link to the Creative Commons license, and indicate if changes were made.

\section{References}

1. J. Michiko, N. Norio, K. Nobuko, K. Katsuko, M.H. Qui, S. Kumiko, S. Kunitada, H. Masao, J. Nat. Med. 60, 217-224 (2006) 
2. Z.J. Zhan, H.D. Sun, H.M. Wu, J.M. Yue, Acta Bot. Sin. 45, 248-252 (2003)

3. J.K. Liu, J.W. Tan, Z.J. Dong, Z.H. Ding, X.H. Wang, P.G. Liu, Helv. Chim. Acta 85, 1439-1442 (2002)

4. J.K. Liu, Drug Discov. Ther. 1, 94-103 (2007)

5. J. Wang, S.L. Wang, X.X. Liu, X.Y. Wan, Y.T. Chen, Acta Microbiol. Sin. 18, 248-252 (1978)

6. E.J. Pedersen, P. Larsen, P.M. Boll, Tetrahedron Lett. 21, 5079-5082 (1980)

7. Y.K. Kim, K.H. Son, J.Y. Nam, S.U. Kim, T.S. Jeong, W.S. Lee, S.H. Bok, B.M. Kwon, Y.J. Park, J.M. Shin, J. Antibiot. 49, 815-816 (1996)

8. M.C. Fernandez, A. Escribano, A.I. Mateo, S. Parthasarathy, E.M.M.D.L. Nava, X.D. Wang, S.L. Cockerham, T.P. Beyer, R.J. Schmidt, G.Q. Cao, Y.Y. Zhang, T.M. Jones, A. Borel, S.A. Sweetana, E.A. Cannady, G. Stephenson, S. Frank, N.B. Mantlo, Bioorg. Med. Chem. Lett. 22, 3056-3062 (2012)

9. P. Barter, K.A. Rye, Trends Pharmacol. Sci. 32, 694-699 (2011)

10. T.A. Rano, G.H. Kuo, Org. Lett. 11, 2812-2815 (2009)

11. G.J.D. Grooth, A.H.E.M. Klerkx, E.S.G. Stroes, A.F.H. Stalenhoef, J.J.P. Kastelein, J.A. Kuivenhoven, J. Lipid Res. 45, 1967-1974 (2004)
12. J.A. Sikorski, J. Med. Chem. 49, 1-22 (2006)

13. O. Weber, H. Bischoff, C. Schmeck, M.F. Böttcher, Cell. Mol. Life Sci. 67, 3139-3149 (2010)

14. P.J. Barter, H.B. Brewer, M.J. Chapman, C.H. Hennekens, D.J. Rader, A.R. Tall, Arterioscler. Thromb. Vasc. Biol. 23, 160-167 (2003)

15. O. Prakash, R. Roy, S. Agarwal, F.A. Hussaini, A. Shoeb, Tetrahedron Lett. 28, 685-686 (1987)

16. B.M. Kwon, J.Y. Nam, S.H. Lee, T.S. Jeong, S.U. Kim, K.H. Son, Y.K. Kim, K.H. Han, S.K. Kim, S.H. Bok, Tetrahedron Lett. 36, 6487-6490 (1995)

17. B. Dockerill, J.R. Hanson, M. Siverns, Phytochemistry 17, 572-573 (1978)

18. A. Loukaci, O. Kayser, K.U. Bindseil, K. Siems, J. Frevert, P.M. Abreu, J. Nat. Prod. 63, 52-56 (2000)

19. J.D. Connolly, R. McCrindle, R.D.H. Murray, A.J. Renfrew, K.H. Overton, A. Melera, J. Chem. Soc. Org. 3, 268-273 (1966) 